University of Nebraska - Lincoln

DigitalCommons@University of Nebraska - Lincoln

2-1-1994

\title{
Unfastening the Electoral Connection: The Behavior of U.S. Representatives when Reelection is No Longer a Factor
}

John R. Hibbing

University of Nebraska-Lincoln, jhibbing1@unl.edu

Rebekah Herrick

Michael K. Moore

Follow this and additional works at: https://digitalcommons.unl.edu/poliscifacpub

Part of the Political Science Commons

Hibbing, John R.; Herrick, Rebekah; and Moore, Michael K., "Unfastening the Electoral Connection: The Behavior of U.S. Representatives when Reelection is No Longer a Factor" (1994). Faculty Publications: Political Science. 12.

https://digitalcommons.unl.edu/poliscifacpub/12

This Article is brought to you for free and open access by the Political Science, Department of at DigitalCommons@University of Nebraska - Lincoln. It has been accepted for inclusion in Faculty Publications: Political Science by an authorized administrator of DigitalCommons@University of Nebraska - Lincoln. 


\title{
Unfastening the Electoral Connection: The Behavior of U.S. Representatives when Reelection Is No Longer a Factor
}

\author{
Rebekah Herrick \\ Oklahoma State University \\ Michael K. Moore \\ University of Texas at Arlington \\ John R. Hibbing \\ University of Nebraska-Lincoln
}

\begin{abstract}
While elections are essential to a democracy, it is commonly believed that the desire to secure reelection causes legislators to engage in many undesirable activities. In this nore, by comparing the behavior of U.S. representatives who have chosen to run for reelection with those representatives who have decided not to do so, we provide evidence of the precise activities induced by electoral concerns. We find that elections cause members to go back to the district more often, to employ more stafr assistants, to attend to roll-call voting more fastidiously, and to be more legislatively active. While these activities are no doubt consistent with the wishes of most constituents, the desire for reelection also encourages members to introduce what is apparently frivolous legislation on topics of litrle familiarity to the member. Those members who are not running for reelection, on the other hand, are more likely to have a successful and tightly focused legislative agenda.
\end{abstract}

Statement 1: Elections force otherwise self-serving legislators to act in a fashion that promotes the common good. Statement 2: Elections cause otherwise sensible legislators to pursue silliness rather than sound policy. Determining which of these diametrically opposed views of elections is closest to the truth is important business. From a theoretical perspective, whether elections are the linchpin or the bane of modern democratic arrangements is as fundamental a question as could be imagined. And from a more immediate, applied perspective, a variety of proposed reforms are currently percolating in the American polity which would alter the role of elections. However, some understanding of the consequences of elections needs to be derived before informed positions on reforms modifying the role of elections can be assumed.

An earlier version of this article was presented at the 1992 annual meeting of the Midwest Political Science Associarion. The data used in this article were originally collected under a grant from the National Science Foundation (SES-8619518).

The Journal of Politics, Vol. 56, No. 1, February 1994, Pp. 214-27

O 1994 by the University of Texas Press, P.O. Box 7819, Austin, TX 78713-7819 
In this research note, we provide evidence on the kinds of behavior encouraged by elections and, more specifically, by the desire for reelection. Our strategy is to compare the activity of those members of the U.S. House of Representatives who are interested in reelection with the activity of those who are not.' As is usually the case when the question is crucial, the answer will be incomplete and in some ways unsatisfying. But what we offer is a beginning and the hope that the inadequacies of our answer will encourage others to do better in addressing the compelling need for empirical evidence on the consequences of the desire for reelection.

\section{ELECTIONS: SOURCE OF RESTRAINT OF SOURCE OF EXCESS?}

According to Schlesinger, "the desire for election and, more important, for reelection becomes the electorate's restraint upon its public officials" $(1966,2)$. He continues, "no more irresponsible government is imaginable than one of highminded men unconcerned for their political fortunes" (1966, 2). In this traditional view, the desire for reelection keeps politicians from running off in dangerous directions; it forces politicians to be accountable. After all, would public officials be receptive to constituent input if those public officials were not worried about their performance in the next election?

But there is a revisionist view which holds that, rather than being the source of accountability and restraint, the desire for reelection is the source of gamesmanship and excess. To illustrate, we consider three of the most oft-cited modern works on elections and Congress.

Mayhew's Congress: The Electoral Connection (1974) is based on the assumption that every member of Congress is motivated solely by the desire for reelection. ${ }^{2}$ He proceeds to show that much of what goes on in Congress can be explained by recalling this assumption. But the resulting picture is far from flattering. Representatives appear to be more concerned with posturing than with making good legislation. They advertise themselves; they take positions in hopes of obtaining "play" back home; and they scheme to take credit for various actions. All in all, the idea seems to be that it is better to look good than to do good.

Tufte, in Political Control of the Economy (1978), also questions the benefits of the desire for reelection. Tufte details the avalanche of benefits unleashed upon constituents by presidents and members of Congress just prior to elections. It is

\footnotetext{
'A similas strategy has recently become popular in some portions of the rational choice literature, although the focus is usually confined to roll-call voting activity (see, for example, Lott and Roed 1989; Lott 1990; and Zupan 1990).

'Of course, Mayhew recognized that other motivations are present. In fact, the last quarter of The Electoral Connection is devoted to a discussion of the desire of members to "keep Congtess afloat" by, among other things, serving on institutional maintenance committees which frequently are thought to be either electorally dangerous or at least electorally unrewarding. For additional treatments of the richness of legislaturs' motivations see Fenno 1973 and Hall 1989.
} 
thought that this generosity will put people in the correct frame of mind for the election. In the short term vorers seem to display the intended favorable reaction to the politicians deemed responsible for the largess, but in the long term the reelection-driven behavior of politicians creates, according to Tufte, "a lurching stop-and-go economy . . . [and] . . a bias toward policies with immediate, highly visible benefits and deferred, hidden costs" $(1978,143)$. Recent research raises questions about the extent to which the political business cycle (see, for example, McCallum 1978; Lowery 1985; Beck 1987; Kamlet and Mowery 1987; and Lewis-Beck 1988) and economic voting in congressional elections (see especially Erikson 1990a and 1990b) are empirical realities, but the fact remains that numerous scholars as well as ordinary citizens harbor suspicions that politicians would and perhaps do readily sacrifice sound fiscal policy for improved reelection prospects.

In a similar vein, Fiorina $(1977 ; 1989)$ speculates that members of Congress, because of their desire to secure reelection, deliberately enlarge the bureaucracy for electoral benefit. They do this because, with a larger bureaucracy, constituents are more likely to need assistance in dealing with the federal government. It is common for constituents to seek such assistance from members of Congress who cheerfully render it partially due to the electoral rewards they expect such activity to produce. Other things being equal, a constituent is more likely to vote for a representative who "took on" the bureaucracy for them than for one who did not. While some might question whether members of Congress are this machinating, once again we encounter an allegation that policy decisions are being made on the basis of concerns over elections rather than the national welfare.

This list could go on at some length. Politicians as recent as Margaret Thatcher, Ronald Reagan, and George Bush have been accused of going to war because of electoral reasons. Not long ago, Congress initiated an investigation into charges that in 1980 the Reagan campaign team undertook steps to delay the release of the hostages in Iran in order to deny Jimmy Carter an "October surprise." Conclusive support for these charges was not forthcoming, but the facr that they were taken seriously by serious people is instructive. We can be certain that over the years lies have been told, crimes have been committed, and responsibilities have been neglected all because of the desire to be elected or reelected.

It is our contention that before informed positions can be assumed on the role of elections in shaping legislators' behaviors empirical evidence needs to be provided on the activities in which members engage apparently because of electoral concerns. But such evidence is difficult to locate. For example, the three essays mentioned above - those by Mayhew, Tufte, and Fiorina - have much to say about the manner in which behavior is influenced by the desire for reelection. But Mayhew and Fiorina provide no evidence beyond two case studies, numerous anecdotes, and some persuasive prose. Tufte presents more in the way of systematic data, although his procedures and conclusions have been subjected to withering critiques (for a summary see Lewis-Beck 1988) and his systematic data pertain 
more to policy outcomes rather than policy actions by policymakers. On the latter he relies heavily on anecdotes from the Nixon presidency among others.

Thus, at present, political scientists are not able to provide precise evidence on how individual politicians react to electoral pressures. This means we are not making a significant contribution to the debate on the role of elections beyond the interjection of reasoned conjecture. We hope to make partial amends in this article.

\section{RESEARCH DESIGN}

The plan is simple. It relies upon the fact that, despite the relatively long congressional careers typical in the modern era, every two years a significant number of representatives decide not to seek reelection. Some run for higher office, usually the Senate, but our primary focus will be on those who not only fail to seek reelection to the House but who also do not, at least immediately, run for any other elective office. These are people, then, who have by all appearances unfastened their electoral connection and who thereby provide us with some leverage on the question of what it is that the desire for reelection causes members of Congress to do.

We begin by comparing those under the influence of the desire for reelection with those who are not under that influence (those seeking election to a different office are excluded from this analysis). We then proceed to slightly more complicated comparisons in which we attempt to take into consideration such factors as the previous behavior of retirees and the fact that some differences between retirees and nonretirees may be due to the greater seniority of retirees relative to the control group.

The time period covered is $1955-1985$ and the dependent variables employed include an unusually broad range of behavioral indicators: roll-call activity, bill introductions, amendments offered, speeches given, legislative specialization and efficiency, travel to the home district, and the number of personal staffers retained. ${ }^{3}$

${ }^{3}$ The dependenc variables are measured in the following manner: Bill Introductions - the number of public bills ineroduced by a member (resolutions were excluded). Amendments - the number of amendments a member offered on the floor to public bills. Speeches-the number of speeches a member gave which were relevant to public bills. Legislative Specialization-the number of bills introduced by a member which were referred to the committee roceiving the most bills from that member divided by the tocal number of bills introduced by that member (only calculated for members who introduced at least five bills-this restriction also applies to efficiency). Legislative Efficiency- the ratio of the number of bills introduced by a member which were reported out of committee with double counting for those bills passing the entire House (the denominator is the total number of bills introduced by the member in that particular Congress). Tolal Staff-the total number of personal staffers working for the member. District Staff-the percent of total staff who are assigned to district affices. Trips Home-the total number of trips to the home district (for which members requested reimbursement) during the first year of the congress. Roll Call Attendance - the percent of all roll-call votes on which the member voted. All data collected by the authors are from Congressional Quarterly, Reporis of the Clerk of the House. Congressional Staff Directory, the Congressional Record Index, and the ICPSR Data Sel Voting Scores for Members of the United Siates Congress (1945-1982). In our composite data set, information on trips home prior to the Ninety-second Congress and staff utilization prior to the Eighty-sixth Congress was unavailable. 
Of course no set of objective indicators can pretend to capture the overall essence of what members do, but this group of variables should be sufficient to provide an initial look at the behaviors members undertake because of electoral considerations.

\section{EXPECTATIONS}

But just what do we expect to happen when electoral concerns are removed? For some of our dependent variables, the expectations are obvious. Compared to their colleagues, those representatives who are not worried about reelection will almost certainly be less likely to travel back to the district and to show up for every roll-call vote. These tasks are energy draining and disliked by most members. They do them because a poor attendance record either at home district events or on roll-call votes can be turned into a serious issue in the next campaign. When this possibility is removed by the decision to retire, travel home and travel to the floor to cast a vote are both likely to diminish.

It is also quite possible that, without the electoral connection, members will be less likely to maintain a full contingent of staffers and to send these staffers to district rather than Washington offices. After all, the motivation to maintain an active and visible district presence is reduced by the decision not to seek reelection. Additionally, staffers probably begin to drift toward other jobs and replacing them becomes difficult and less necessary.

Activities associated with the legislative side of congressional service also probably begin to wane. We expect that members not facing reelection are less likely to introduce bills, to offer amendments to other bills, and to make speeches on the floor. Undoubtedly, members remain commitred to certain issues and causes even after they decide to retire, but the need to please a broad range of constiruents likely encourages representatives to introduce bills and give speeches that they otherwise would not.

A similar logic is present in our expectation that removal of the electoral connection will cause members' legislative agenda to be more focused. The need to tell constituents that "I have introduced a bill to ..." is not as strong without the pressure of an upcoming reelection bid. Lacking such pressure, members will be free to concentrate on the legislation that matters to them and this freedom is likely to translate into a more tightly defined issue area.

But there is one variable for which theoretical expectations are unclear: the degree to which representatives are able to move their bills out of committee and out of the House. The lame-duck status of the member may make it less likely that he or she will be both able and willing to do the hard background work and negotiating required to shepherd a bill over the legislative terrain. So, it might be thought that legislative efficiency would drop upon removal of the electoral connection. On the other hand, if we are correct about fewer bills being introduced and about the remaining bills pertaining to topics about which the member cares, the decision to retire should produce increased legislative efficiency. Spccifically, retiring members may see their last congress as a final opportunity to secure passage of key 
legislation and may work extra hard to ensure its passage. All and all, it is likely that efficiency will either not differ dramatically for retirees and nonretirees or perhaps it will be slightly higher for retirees. ${ }^{*}$ Our larger theoretical expectation is that testing for these anticipated relationships will reveal much about what members do and do not do as a result of electoral pressures.

\section{INITIAL FINDINGS}

Analyses are never as clean as first imagined, and it is time to introduce some caveats and apologies. When the data are analyzed Congress by Congress the number of members unaffected by the desire for reelection (voluntary retirees) occasionally dips to dangerously low (for purposes of analysis) levels. ${ }^{5}$ This makes drawing conclusions slightly risky, particularly since the crutch of significance tests is not entirely appropriate when the population rather than a sample is being employed, as is the case here. The availability in the data set of 14 separate Congresses, however, should provide a big assist in efforts to discern patterns in the numbers.

Table 1 presents our baseline results produced when those members influenced by reelection are compared with those members not so influenced. We find that legislative activity is almost always reduced by an unfastening of the electoral connection. In all but two of the 14 Congresses analyzed, the mean number of speeches given and amendments offered by those who are retiring is significantly less than the mean number of those who are running for reelection. The introduction of bills is also lower for retirees in nine of the 14 Congresses although overall differences are not statistically significant. The magnitude of the change produced by the decision to retire varies but is usually in the range of 8 to 12 speeches less, one amendment less (the average representative only introduced a little more than two amendments per Congress across this time period) and five or six bill introductions less.

\footnotetext{
+A second arca of theoretical uncertainty invulves party support on roll-call votes. Traditionally, congressional scholars have hypothesized that as electoral pressures intensify, members move away from the orthodox party line. This logic would lead us to expect that complete removal of electoral pressures allows representatives to fee back to the party line. At the same time, many members may have voced with the wishes of their party leaders for reasons such as the need for campaign assistance from the party, the desire for a formal position in the House hierarchy, or because of simple cajoling from party bigwigs. Freed from these pressures and concerns, party support may diminish as a result of the decision to retire. The results (not presented) reflect these theoretical uncertainties-party support, on average, increases about as often as it decreases subsequent to the unfastening of the electoral connection. The differences between those leaving public office and those seeking reelection were not significant.

${ }^{3}$ Across the 14 Congtesses, the mean $N$ for retirees is about 27 while the mean $N$ for those seeking reelection is approximately 390 (slightly less for the specialization and efficiency scores since they are based only on members introducing at least 5 bills). Of course, to the extent the decision to retire is nor made precisely at the break between the last and second to last Congress, the differences we present will be reduced. Since many decisions undoubtedly do come at other times, we are presenting a conservative test of our hypotheses.
} 


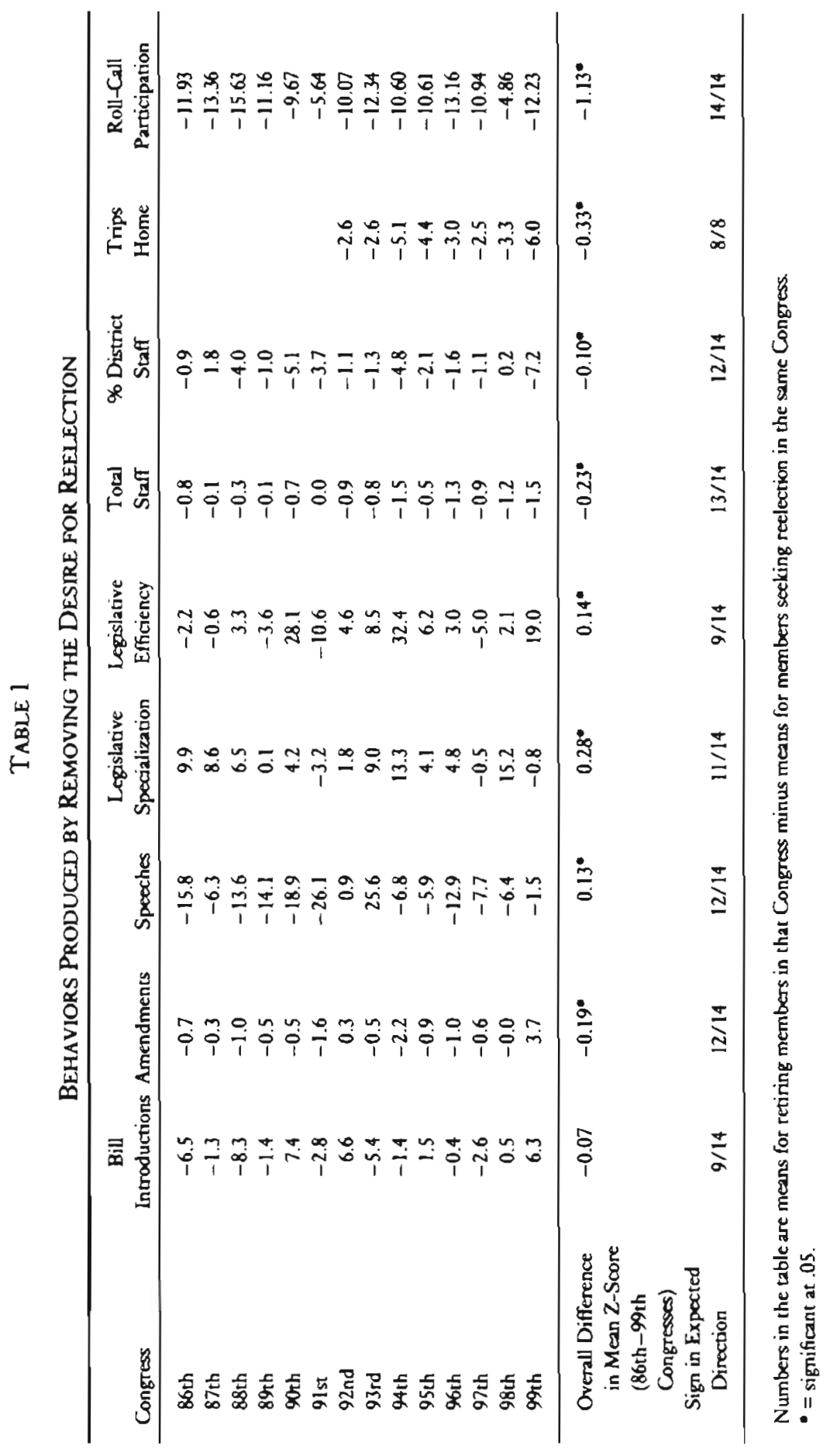


Participation in roll-call votes takes a corresponding drop. On average, in their last Congress, retirees vote in $11 \%$ fewer roll calls than their nonretiring colleagues. ${ }^{6}$ And a similar story is found with regard to travelling back to the home district. Retirees went home less than their colleagues in each of the eight Congresses for which we have data, usually by five or six trips per Congress (the data in table 1 are only for trips home in the first session of each Congress). And retiring members were much less likely to take advantage of the full allotment of personal staffers available to them and were somewhat less likely to assign those staffers to district rather than Washington offices. Each of these differences is statistically significant.

But perhaps the most important finding pertains to the variety of bills introduced by members, the variable we call specialization. Freed of the electoral connection, it appears members no longer feel the pressure to introduce bills on all sorts of topics. Thus, in all but three of the 14 Congresses, those who were voluntarily retiring had a more focused legislative agenda. Compared to their colleagues, retirees were much more likely to introduce bills that dealt with just one or two topics. Specialization scores usually were about 7 to 10 percentage points higher for retirees and this difference easily meets traditional standards of statistical significance. For those who value legislative specialization and expertise, this would seem to be evidence of a negative consequence of electoral pressures.

Previous research and theory provided no clear guidance in terms of expectations for legislative efficiency (the extent to which a member's bills were passed by committee and possibly by the whole House). Somewhat surprisingly, perhaps, even though retirees may have been expected to have "given up" on their legislative agendas as their House careers wound to a close, the batting avcrage of retirees was generally higher than that of members seeking reelection. The percentage of bills moving at least part of the way through the legislative process was higher for retirees in nine of the 14 Congresses (and significant for the entire time period), often by sizable percentages. Again, this is indirect evidence of a negative consequence of electoral pressures. This time the pressures seemingly encourage actions designed to allow a member to take credit for something that is in actuality meaningless-the introduction of bills which everyone knows are unlikely to go anywhere.

\section{FIRST DIFFERENCING}

But such blunt comparisons have the potential of being misleading. It may be, for example, that the retiring class in a particular Congress is unusual. Perhaps it is composed of mostly Republicans who, not surprisingly since the Democrats were

\footnotetext{
- Of course, there are solid grounds for expecting that, when they do participate, the roll-call voting of retirees and nonretirees may be quite different. For example, Jacobson (1992) demonstrates that on the controversial budget vote of 1990 , retiring members were much more likely to vote in the "unpopular but responsible" way than were those members attempting to secure reelection (that is, retiring members were more likely to vote for a package that included tax increases and spending cuts). This line of research holds much promise for those interested in the consequences of electoral pressures on legislative behavior.
} 
the majority party in the House for the entire time period covered by our analysis, tend to have lower percentages of their bills making it out of committee and out of the House. Or perhaps a retiring class just happens to be composed of representatives who have always been among the least likely to participate in roll-call votes. With retiring classes being so small, such possibilities must be taken seriously.

Another potential problem with the uncontrolled data presented in table 1 is that retirees tend to be senior members and, particularly in the early portions of the period under study, senior and junior members were markedly different on many of these indicators of behavior (see Matthews 1960). Further, with other factors controlled, decisions to retire voluntarily are encouraged by narrow vote margins in the previous election (see Moore and Hibbing 1992). Perhaps these narrow margins, in turn, are caused by insufficient attention to constituents or by some other perceived failing. ${ }^{7}$ The larger point is, those members predisposed to pass up the opportunity to run for reelection may be different from those who do run, and these differences, rather than the actual decision to sever the electoral connection, may be responsible for the results presented in table 1 .

To control for these other factors we have relied upon computations which subtract the mean behavioral change over time from the behavior in the Congress in question. It is our working hypothesis that those members who are voluntarily retiring will change more from the behavioral patterns they established earlier in their own career than will those members who are running for reelection. An example is in order. Instead of just comparing the behavior of a typical retiree with a typical nonretiree in the Ninety-ninth Congress, in table 2 the comparison involves the difference between each member's behavior in the Ninety-ninth Congress and their pre-Ninety-ninth behavior. Pre-Ninety-ninth Congress behavior

\footnotetext{
'Though this particular alternative explanation is perfectly reasonable, it does not appear to withstand analysis. First of all, in terms of electoral support in the previous election, in a bivariate sense retirees are actually safer than nonretirees $(68 \%$ mean share of the vore for retirees during our time period to $65 \%$ for nonretirees). As noted, however, when other variables (such as tenure) are included in the equation we discover that, given their level of experience, retirees were slightly more marginal in the previous election than nonretires. More to the point perhaps, while there is something to the link between electoral insecurity and the decision to retire, the link between attention to constituents and subsequent electoral margin has proved illusive. Though this link is widely assumed to exist (see especially Fiorina 1977 and 1989), systematic analysis has all too frequently failed to document it (see, for example, Johannes and McAdams 1981). Finally, a quick comparison of retirees and nonretirees in the retirees' penultimate Congress suggests that there are only extremely minor differences in constituency attention and related variables between the two groups before the decision to retire was made. Moreover, to the extent differences did appear, those who turned out to be just a few years away from voluntary retirement (as could be expected given their greater than average age and tenure) were actually a little less acrive in such things as traveling back to the district ( 1.73 fewer trips home than those who did not retire after the next Congress), sending staffers back to the district ( 1.70 fewer staffers assigned to the district), and participating in roll-call votes ( $2.33 \%$ lower on the roll-call participation scale). These slightly lower levels of activity mean that the evertual retirees start below the average and thus make the sizable drop for retirees between the penultimate Congress and their final Congress (see table 2) even more suggestive of the imporance of the electoral connection.
} 


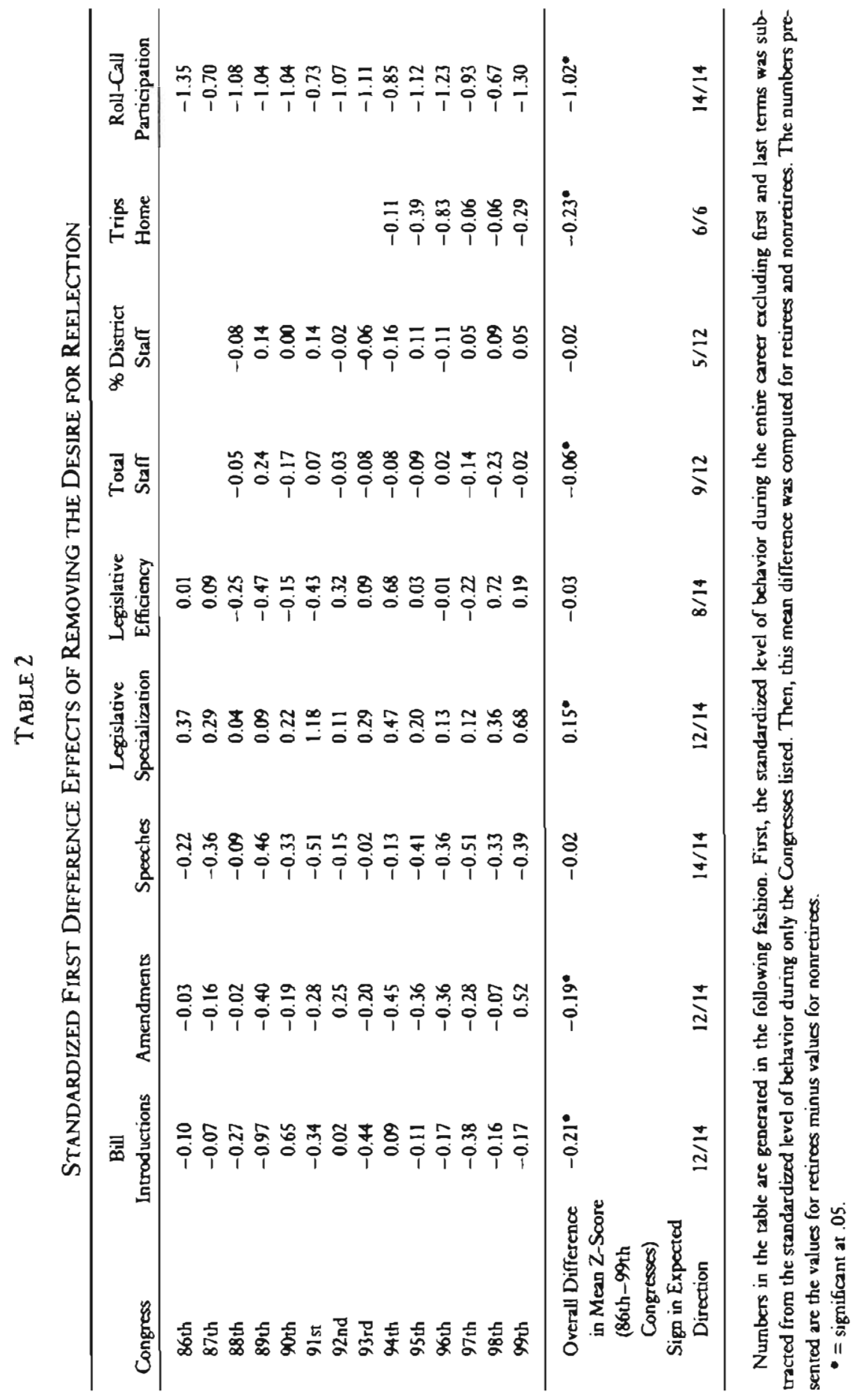


is computed and averaged for however long the House career happened to be (initial terms are excluded since they tend to be atypical). Then this mean figure is subtracted from behavior in the Ninety-ninth Congress (similar procedures were employed for the other 13 Congresses). After performing this computation for each member, retirees were compared to those seeking reelection.

We expect that the mean shift in behavior will be different for retirees as a group and for nonretirees as a group. The differences we expect have been explained in a previous section of this research note. What is distinctive in this portion of the analysis is that by using a first differencing procedure, we have controlled for the established behavior of a member. Thus, the potential problem of an unusual retiring class biasing the results should be removed since the variables now take into consideration past behavior. Moreover, regular aging effects should now be equally reflected for nonretirees as well as retirees.

Table 2 presents the results of this rather complicated computational procedure. The numbers are all expressed in standardized form ( $z$-scores) since comparison of individual behavior across Congresses demand such standardizarion. Over this 30-year period there were tremendous shifts in the actual level of travelling home, bills introduced, mean participation scores and on and on. Interpretation is somewhat more cumbersome, but by standardizing we control for these aggregate shifts in the congressional environment, and we are therefore able to isolate changes in individual behavior.

Now to the results themselves. On the whole, table 2 indicates that the relationships detected in table 1 are not due to retirees being atypical individuals or to the fact that retirees tend to be more senior. Instead, with these factors controlled, the direction of the relationships and the consistency with which these relationships appear across time remains almost identical. Legislative activity drops off more sharply for retirees (compared to the rest of their careers) than for nonretirees. Legislative specialization (but not legislative efficiency) increases. And roll-call participation, trips home, total staff employment and assigning staff to district offices all decline, just as they did in table $1 .^{8}$

'Though this paper deals with what happens when the electoral connection is "unfastened," we will make a few very brief remarks about what happens when a representative tries 10 attach to a different constituency by running for higher office. When this happens our results show that members become less active legislatively, presumably because of the rigors of the campaign, but in one aspect of legislative activity, those seeking higher offee are actually more active than their colleagues. In 12 of the 14 Congresses, members seeking higher office introduced more bills than members seeking reelection. Perhaps as a result of the increased activity in this area, the specialization and efficiency scores of progressively ambitious representatives were nearly al ways lower than those of members seeking reelection to the House (again, in 12 of 14 Congresses). On other fronts, members seeking higher office go home less often (at least they ask for reimbursement less often), they use more staffers ( 13 of 14 Congresses), and they participate in fewer roll-call votes. Bear in mind that these differences are based on only about 15 members per Congress who seek election to higher office compared to about 390 members on average seeking reelection (slightly less for the specialization and efficiency measures which were only calculated for members introducing at least $S$ bills in a Congress). 


\section{CONCLUSION}

Our empirical results are clear but still leave room for different interpretations about the values and dangers of elections. Supporters of Statement 1 as well as supporters of Statement 2 (see the very beginning of this article) probably can all use our results to butress their beliefs. Those believing elections encourage accountable, responsible behavior on the part of representatives can note that without elections members miss roll-call votes, introduce fewer bills, pass fewer bills, and do not work as hard at keeping in touch with or servicing the district. Those believing elections encourage irresponsible showboating at the expense of serious work on national policy can note that elections apparently discourage members from having a focused and potentially successful legislative agenda. Instead, elections prod members to spend their time (and taxpayers' money) traveling to the home district, maintaining a large district staff presence, pontificating, introducing symbolic bills, and casting (sometimes) meaningless roll-call votes.

In light of beliefs that elections have consequences for the system, reform proposals reducing the number and/or role of elections have gained popularity. The one presently garnering the most attention is the suggestion that the number of terms legislators are eligible to serve be limited. In 1990 three states, Oklahoma, Colorado, and California, limited the number of terms their legislators could serve (see Copeland and Rausch 1991). In 1992, 14 more states enacted limitations (for background information, see Benjamin and Malbin 1992). Numerous interest groups and nearly $70 \%$ of American adults, according to most surveys, feel limiting legislative terms is a good idea (see Hook 1990). While the main motivation of most of those pushing this reform is not a desire to lessen the influence of elections, its passage would undoubtedly have this effect (at any given time under even 12-year term limits, 73 or $17 \%$ of all representatives and 50 or $50 \%$ of all senators would be statutorily ineligible to seek reelection).

Others would like to lengthen the term of presidents or representatives or both. Virtually every recent president has advocated switching to a nonrenewable sixyear term for their successors. And some observers wish to increase the length of each term of U.S. representatives to four years rather than two. The justification is usually that we will get better government if reelection is not the main focus of attention.

While no research design could generate results depicting the precise consequences of such serious reforms (for example, the behavior of those forced to leave could possibly be different from those leaving voluntarily), our findings help to provide a general sense of the directions in which politicians move when electoral pressures are reduced; they become less active, have less contact with constituents, but adopt a more focused legislative agenda. At this point the dispute naturally shifts to the normative question of the kinds of activities in which we want our elected officials to engage. We do not intend to enter the debate on such a matter here. Instead, we will be content if we have provided empirical grounding for the 
debate on the role of elections by specifying with at least some additional clarity the kinds of behaviors that do and do not tend to be produced by the desire for reelection.

Manuscript submitted 22 January 1992

Final manuscript received I December 1992

\section{REFERENCES}

Beck, Nathaniel. 1987. "Elecrions and the Fed: Is There a Political Monetary Cycle?" American foumal of Political Science 31:194-216.

Benjamin, Gerald, and Michael J. Malbin, eds. 1992. Limiting Legislative Terms. Washington, DC: Congressional Quarterly Press.

Copeland, Gary W., and John David Rausch, Jr, 1991. "The End of Professionalism? The Dynamics of Term Limitations." Presented at the annual meeting of the Southwestern Political Science Association, San Antonio.

Erikson, Robert S. 1990a. "Economic Conditions and the Congressional Vote: A Review of the Macrolevel Evidence." American Journal of Political Science 34:373-99.

Erikson, Robert S. 1990b. "Reply to Jacobson." American Joumal of Political Sclence 34:405-07.

Fenno, Richard F., Jr. 1973. Congressman in Committees. Boston; Little, Brown.

Fiorina, Morris. 1977. Congress-Keystone of the Washington Establishment. New Haven, CT: Yale University Press.

Fiorina, Morris. 1989. Congress-Keystone of the Washington Establishment. 2d ed. New Haven, CT: Yale University Press.

Hall, Richard L. 1989. "Committee Decision Making in the Postreform Congress." In Congress Reconsidered, 4th ed., eds. Lawrence C. Dodd and Bruce I. Oppenheimer. Washington, DC: Congressional Quarterly Press.

Hook, Janet. 1990. "New Drive to Limit Tenure Revives an Old Proposal." Congressional Quarlerly Weekly Report 48: 567-69.

Jacobson, Gary C. 1992. "Deficit Politics and the 1990 Elections." Presented at the annual meeting of the American Political Science Association, Chicago.

Johannes, John R, and John C. McAdams. 1981. "The Congressional Incumbency Effect: Is It Casework, Policy Comparibility, or Something Else?" American Joumal of Political Science 25:512-42.

Kamlet, Mark S., and David C. Mowery. 1987. "Influence on Executive and Congressional Budgetary Priorities, 1953-1981." American Polisical Science Reviem 81:155-78.

Lewis-Beck, Michael S. 1988. Economics and Elections. Ann Arbor, MI: University of Michigan Press.

Lotr, John R., Jr. 1990. "Attendance Rates, Political Shirking, and the Effect of Post-Elective Office Employment." Economic Inquiry 28:133-50.

Lotr, John R., Jr., and W. Robert Reed. 1989. "Shirking and Sorting in a Model of Finite-Lived Politicians." Public Choice 61:75-96.

Lowery, David. 1985. "The Keynesian and Political Determinants of Unbalaneed Budgets." American Journal of Political Science $29: 428-60$.

Matthews, Donald R. 1960. U.S. Senators and Their World. Chapel Hill, NC: University of North Carolina Press.

Mayhew, David R. 1974. Congres: The Electoral Connection. New Haven, CT: Yale University Press. McCallum, B. T, 1978. "The Political Business Cycle." Joumal of Political Economy 44:504-15.

Moore, Michael K., and John R. Hibbing. 1992. "Is It Fun Again to Service in the U.S. Congress?" American Foumal of Political Science 36:801-806.

Schlesinger, Joseph A. 1966. Ambition and Politics. Chicago: Rand McNally. 
Tufte, Edward R. 1978. Political Control of the Economy. Princeton, NJ: Princeton University Press.

Zupan, Mark. 1990. "The Last-Period Problem in Politics: Do Congressional Representatives Not Subject to a Reelection Constraint Alter Their Voting Behavior?" Public Choice 65: 167-80.

Rebekah Herrick is assistant professor of political science, Oklahoma State University, Stillwater, OK 74078.

Michael K. Moore is assistant professor of political science, University of Texas at Arlington, Arlington, TX 76019-0539.

John R. Hibbing is professor of political science, University of NebraskaLincoln, Lincoln, NE 68588. 